\title{
Study on Local Uses of Medicinal Plants in Nayabazar, Pyang and Jamuna VDCs of Ilam District
}

\author{
Raghu Ram Parajuli \\ District Plant Resources Office, Ilam \\ e-mail:parajrr@yahoo.com
}

\begin{abstract}
This paper had documented the indigenous knowledge of local people on the utilization of medicinal plants in Nayabazar, Pyang and Jamuna VDCs of Ilam Distict in Eastern Nepal. People of different castes, Rai, Brahmin, Chhetri, Gurung, Tamang, Limbu, Sherpa, Sunar, Kami, Magar and Newar live in the study area. The study was carried by collecting the information through interaction with people, questionnaire and field observation. Eighty four plant species were found belonging to 43 families and 76 genera from the study. Four species of Pteridophytes, one species of Gymnosperm and 79 species of Angiosperms were recorded . Botanical names, families, local names, life forms, useful parts, concerned ailments and mode of application of plants used as medicine have been listed in tabular form. Herbaceous plants were found dominant over shrubs and trees as the medicinal sources. Cough, asthma, fever, urinary and gastro-intestinal disorders were most common diseases among the people. Plants belonging to the families Asteraceae, Rutaceae and Rosaceae were found more frequently used. Most of the local people are familiar with medicinal plants and they have started cultivation of some the medicinal plants like Swertia chirayita, Lilium nepalense, Berginia ciliata, Taxus wallichiana, Asparagus racemosus and Valeriana jatamansi.
\end{abstract}

Key words: medicinal value, ethnobotany, traditional use, local people

\section{Introduction}

Ethnobotany deals about the relationship of plants and human beings. It is the science that focuses on the people-plant relationship in a multidisciplinary manner, incorporating not only collection and documentation of indigenous knowledge but also ecology, economy, pharmacology, public health and other disciplines(Kunwar \& Bussmann 2008). Each and every plant has medicinal value and all medicinal plants contain some chemical constituents such as alkaloids, glucosides, flavenoids, resins, tannins, steroids, gums, etc.(Pandey 1995). Regveda and Atharvaveda, which date back to 2000-1000 BC, and several post Vedic treaties viz. Charak Samhita (100 AD), Sushruta Samhita (800900AD), Dhanwantari Nighantu (1200AD), Raj Nighantu (1600 AD) to name a few, are the important ancient sources of information on medicinal plants (Patel 2010) The traditional knowledge of local people has high ethnobotanical importance. The rural people of Nepal continue to depend on the local therapy for their health care as it is cheap, convenient and readily available (Manandhar 2002). Rajbhandari(2001) has compiled the information on ethnobotanical uses of 562 species of plants. Almost $80 \%$ of the population in the developing countries rely on traditional medicines. Due to lack of doctors and modern medicine, inaccessibility to health centers, cultural preferences and effectiveness of the medicinal plants people prefer local therapy(Gillam 1989, Bhattarai et al. 2006).

There have been various studies on medicinal plants and their traditional use in different parts of Nepal(Manandhar 1980, Rai 2007, Bhatta \& Chhetri 2009, Bhattarai et al. 2006, Acharya 2009, Srivastav 2009, Parajuli 2011, 2012) Different plant parts possess different components that are effective to control the diseases. Plant essential oils are found to possess the antifungal properties ( Parajuli 2003). It is a fact that a large number of medicinal plants and associated indigenous knowledge on their uses still remain without proper documentation. The present study was carried with the objective of documenting the medicinal plants and their use by the tribal people of the study area and to bring into highlight the indigenous knowledge so as to preserve valuable plant genetic resources. 


\section{Study area}

Nayabazar, Pyang and Jamuna VDCs of Ilam district were chosen for the ethnobotanical study. Nayabazar, Pyang and Jamuna are $20 \mathrm{~km}, 15 \mathrm{~km}$ and $24 \mathrm{Km}$ far respectively from Ilam headquater Ilam. Nayabazar, Pyang and Jamuna VDCs have area of $21.51 \mathrm{sq} \mathrm{km}, 24.32 \mathrm{sq} \mathrm{km}$ and $28.87 \mathrm{sq}$ $\mathrm{km}$ respectively. The study area is very rich in natural resources and diverse caste people (Rais, Limbus, Gurungs, Brahmins, Chhetris, Tamangs, Magars, Kamis, Sunuwars, Newars, Sherpas) of different cultures(Hindus, Budhdhists and Kirats). The study in the traditional uses of medicinal plants have not so far been carried in this area. It is the highly resourceful area in terms of Amomum subulatum(Alainchi) cultivation. Since last few years Alainchi is threatened due to different diseases and people are involved more in felling down the trees for their income and livelihood. The dominant tree species are Alnus nepalensis(Uttis) and Macaranga pustulata(Maleto) That is why biodiverisity is in risk due to human activities. Thus, it is felt essential to document the traditional knowledge of local people about the biological resources and make them aware for conservation.

\section{Methodology}

The field survey was carried out during 2010 to 2011 covering all seasons to collect information on the plants of medicinal values. The field visits were accompanied with the local healers, traders, farmers, teachers, students, community forest user groups and general public. Plants were collected in their flowering and fruiting stage as far as possible from the natural habitat. While collecting the individual plant species a thorough observations were been made regarding their natural habitat, distribution, vegetative and reproductive characters. The ethnobotanical information on the medicinal uses have been gathered from the old people, local healers and cultivators using semi-structured questionnaires. Some people were interviewed personally. Then, an interaction was held to discuss and verify the ethnobotanical information obtained. Field identification of sampled medicinal plants was done with the help of local name, habit, vegetative and reproductive characters. The plant species were then prepared for herbarium specimens systematically and identified with the help of the knowledge available in the field visit, characters observed and listed and verified with the literatures(Manandhar 2002, Polunin \& Stainton 1984, Anonymous 2007, Anonymous 2001, Baral \& Kurmi 2006, Shrestha \& Shrestha 2061(BS), Parajuli \& Thapa 2066 (BS)). Then, the documented ethnobotanical information of the identified plants was arranged in alphabetical order of botanical names alongwith related families, local names, life forms, parts used, concerned ailments and mode of application as given in Table 1.

Table 1. Ethnobotanical information documented from Naya Bazar, Pyang and Jamuna VDCs, of Ilam districts, 2010- 2011

\begin{tabular}{|c|c|c|c|c|c|c|c|}
\hline S.N & $\begin{array}{l}\text { Botanical } \\
\text { Name }\end{array}$ & Family & Loc al Name & Life form & Parts Used & Alments & $\begin{array}{l}\text { Mode } \\
\text { of } \\
\text { applica } \\
\text { tion }\end{array}$ \\
\hline 1 & $\begin{array}{l}\text { Achyranthes } \\
\text { aspera }\end{array}$ & Amaranthaceae & Apamarga & Herb & Whole plant & $\begin{array}{l}\text { Cough, dropey, } \\
\text { piles, } \\
\text { stomachache }\end{array}$ & Juice, paste \\
\hline 2 & $\begin{array}{l}\text { Achyranthes } \\
\text { bidentata } \mathrm{Bl} \text {. }\end{array}$ & Amaranthaceae & Datiwan & Herb & Root & $\begin{array}{l}\text { Hypertension, } \\
\text { rheumatism, }\end{array}$ & Juice, paste \\
\hline 3 & Alium cepa & Amaryllidaceae & Pyaz & Herb & Whole plant & $\begin{array}{l}\text { Asthma, malarial } \\
\text { fever, bronchitis }\end{array}$ & Vegetable, juice, \\
\hline 4 & $\begin{array}{l}\text { Alium } \\
\text { sativum }\end{array}$ & Amarylidaceae & Lasun & Herb & Whole plant & $\begin{array}{l}\text { Cough, } \\
\text { bronchitis, } \\
\text { asthrna, fever, } \\
\text { constipation }\end{array}$ & $\begin{array}{l}\text { Vegetable, paste of } \\
\text { bulb, oil. }\end{array}$ \\
\hline 5 & $\begin{array}{l}\text { Rhus } \\
\text { chinensis } \\
\text { Miller }\end{array}$ & Anacardiaceae & Vakimlo & Shrub & Fruits & $\begin{array}{l}\text { Paralysis, } \\
\text { diarrhea, } \\
\text { dysentery }\end{array}$ & $\begin{array}{l}\text { Sseed powder, } \\
\text { fruits }\end{array}$ \\
\hline 6 & $\begin{array}{l}\text { Acorus } \\
\text { calamus L. }\end{array}$ & Araceae & Bojho & Herb & Rhizome & $\begin{array}{l}\text { Cough, asthrna, } \\
\text { tonsil }\end{array}$ & Juice, che wing \\
\hline
\end{tabular}


Raghu Ram Parajuli/Study on Local Uses of Medicinal

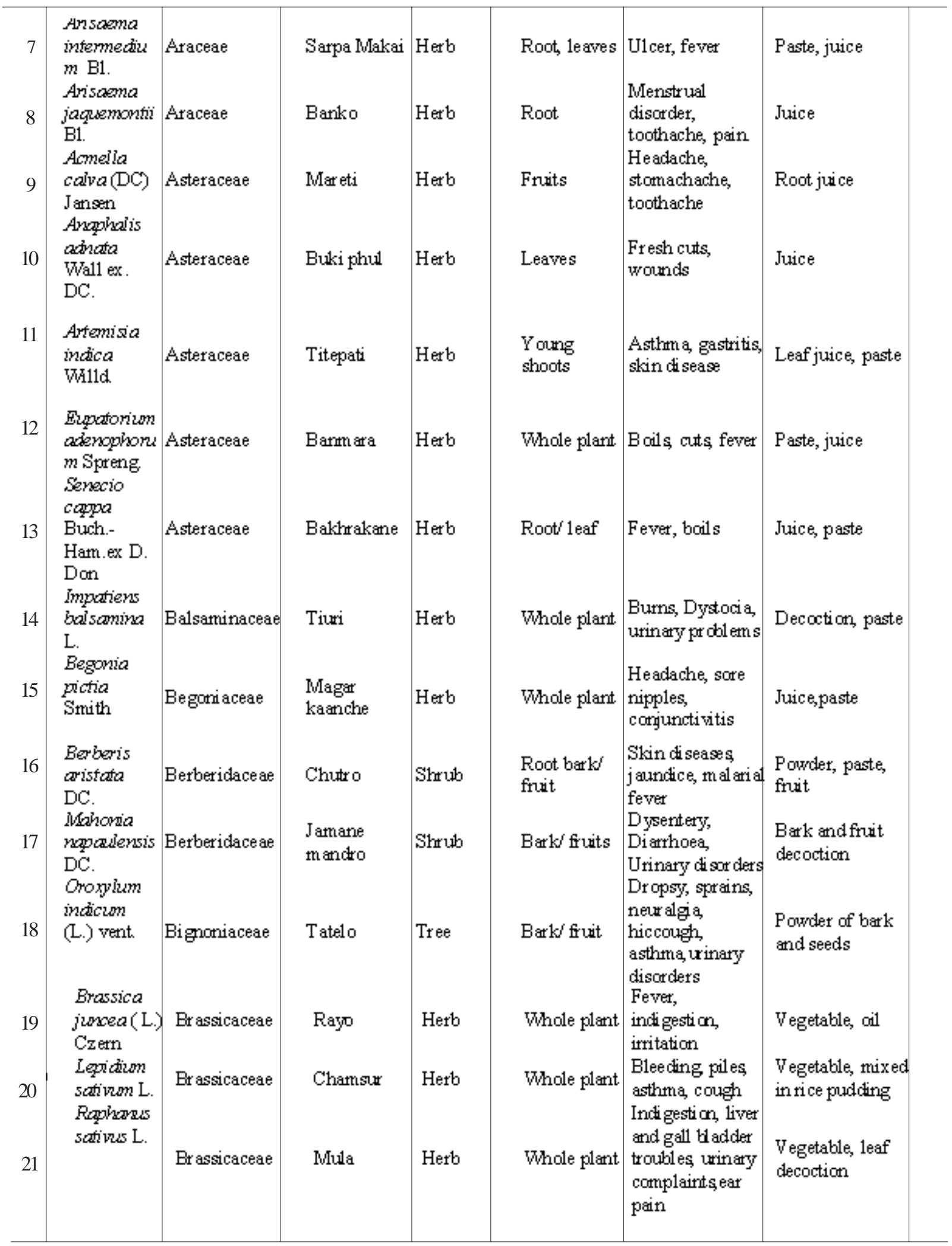


Nepal Journal of Science and Technology Vol. 14, No. 1 (2013) 57-66

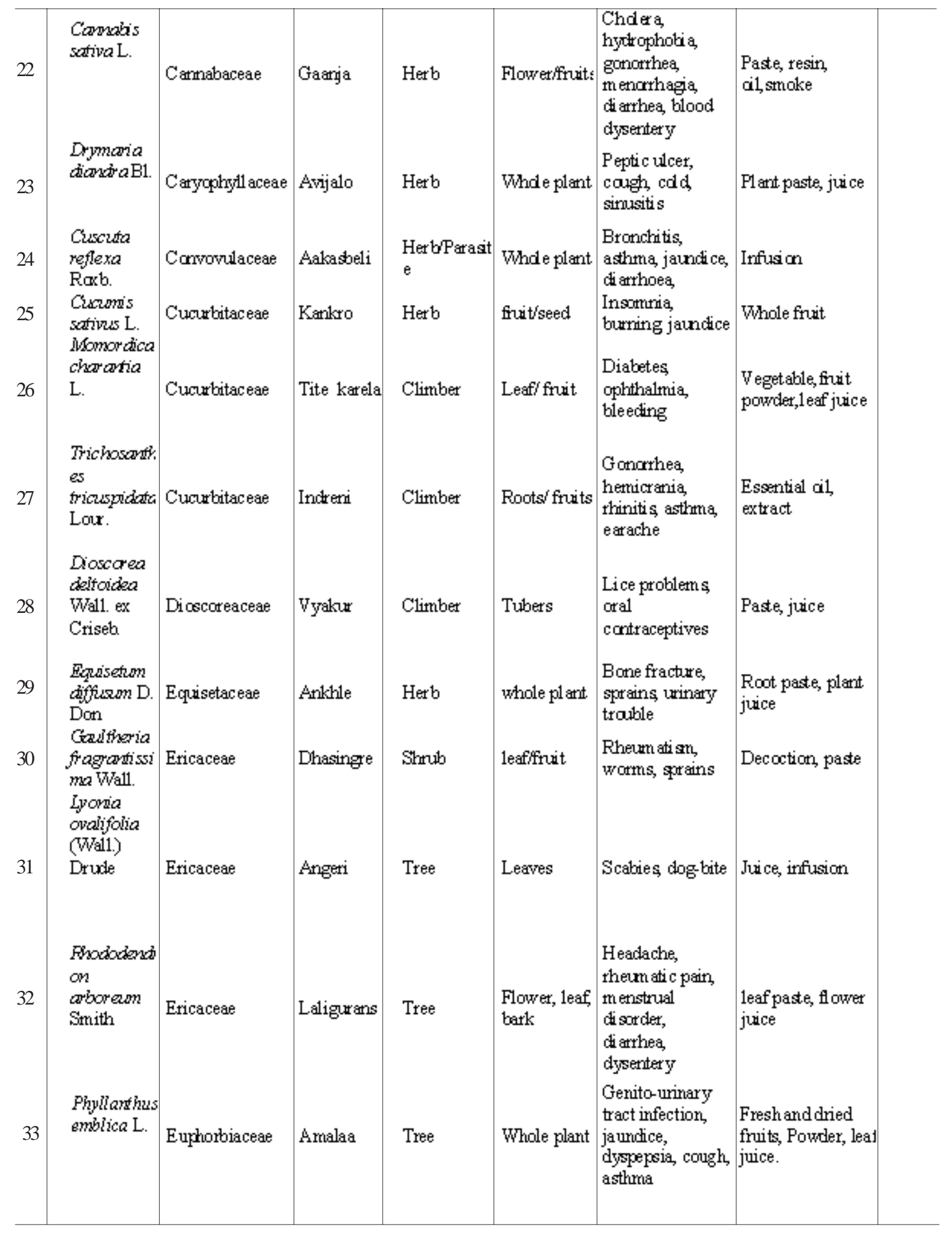


Raghu Ram Parajuli/Study on Local Uses of Medicinal

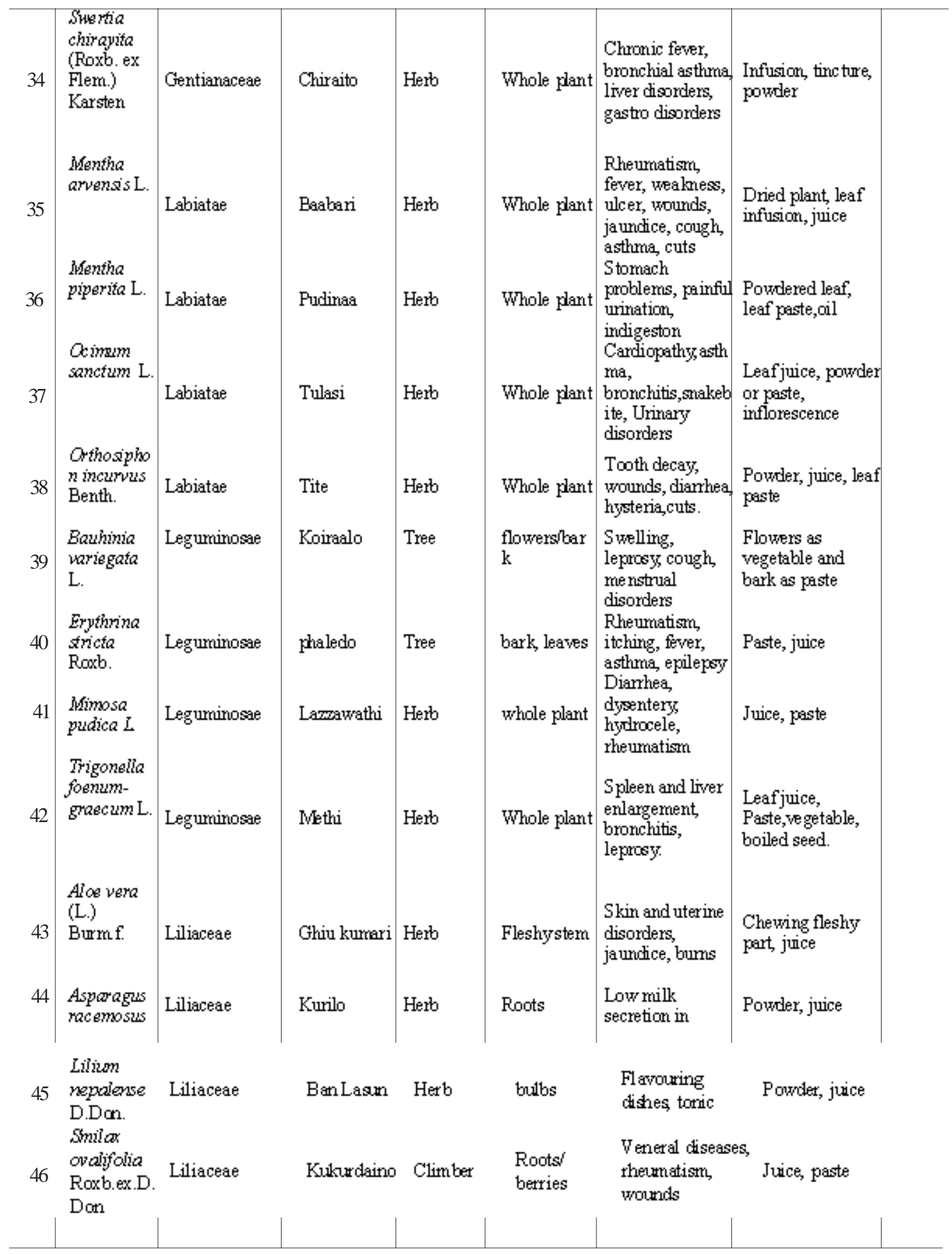


Nepal Journal of Science and Technology Vol. 14, No. 1 (2013) 57-66

\begin{tabular}{|c|c|c|c|c|c|c|c|}
\hline 47 & $\begin{array}{l}\text { Lycopodium } \\
\text { clav atum } \mathrm{L} \text {. }\end{array}$ & Lycopodiaceae & Naagbeli & $\begin{array}{l}\text { Creeping } \\
\text { ferr }\end{array}$ & S trobihss & $\begin{array}{l}\text { Lung and Kidney } \\
\text { problem, Uringry } \\
\text { disorder }\end{array}$ & S pores paste, juice \\
\hline 48 & $\begin{array}{l}\text { Ficus } \\
\text { carica L. }\end{array}$ & Moraceae & Nevaro & Iree & rootifnuits & $\begin{array}{l}\text { Constipation, } \\
\text { warts }\end{array}$ & $\begin{array}{l}\text { Paste, chewing } \\
\text { fruits }\end{array}$ \\
\hline 49 & $\begin{array}{l}\text { Ficus } \\
\text { nerijolia } \\
\text { Sm.Yar. }\end{array}$ & Moraceae & Peepal & Iree & 1atex & $\begin{array}{l}\text { Boils on the } \\
\text { tongue }\end{array}$ & Paste \\
\hline 50 & $\begin{array}{l}\text { Psidium } \\
\text { guajava L. }\end{array}$ & Myrtaceae & Ambok & Iree & fruits/leaves & $\begin{array}{l}\text { Constifation, } \\
\text { diarthoea, ulcers, } \\
\text { toothache }\end{array}$ & Fruits. Paste, juice \\
\hline 51 & $\begin{array}{l}s \\
\text { ouriculdata } \\
\text { (L.) Iriment }\end{array}$ & $\begin{array}{l}\text { Nephrolepidacea } \\
\text { e }\end{array}$ & Partiamlala & Fem & $\begin{array}{l}\text { I uberaus } \\
\text { root }\end{array}$ & $\begin{array}{l}\text { Indigestion, } \\
\text { fever, cold, oougr }\end{array}$ & I uber juice \\
\hline 52 & $\begin{array}{l}\text { Oxalis } \\
\text { corniculata } \\
\text { L. }\end{array}$ & Oxalidaceae & Chariamilo & Herb & Whole $p$ lant & $\begin{array}{l}\text { Indigestion, } \\
\text { diarthea, piles, } \\
\text { anemia, eye } \\
\text { problems }\end{array}$ & $\begin{array}{l}\text { Powder, pas te, fres } 1 \\
\text { juice }\end{array}$ \\
\hline 53 & $\begin{array}{l}\text { Phytolecea } \\
\text { acinosa } \\
\text { Roxb. }\end{array}$ & Phytolacsacease & Jaringo & Herb & Whole plant & $\begin{array}{l}\text { Indigestion, Eye } \\
\text { disorders }\end{array}$ & $\begin{array}{l}\text { Seed, leaves as } \\
\text { regetable }\end{array}$ \\
\hline 54 & $\begin{array}{l}\text { Cynodon } \\
\text { dactylon } \\
\text { (L.)Pers }\end{array}$ & Poaceare & Dubo & Herb & Whole plant & $\begin{array}{l}\text { Epistaxis, } \\
\text { scabies, } \\
\text { cut,wound, epileps } \\
\text { y,piles }\end{array}$ & Plant paste, juice \\
\hline 55 & $\begin{array}{l}\text { Imperata } \\
\text { cylindrica } \\
\text { (L.) }\end{array}$ & Poaceae & Sinu & Herb & Roots & $\begin{array}{l}\text { Diarrhea, } \\
\text { dysentery }\end{array}$ & Paste, juice \\
\hline 56 & $\begin{array}{l}\text { Bealyois } \\
\text { Thy sanolas } \\
\text { na maxima } \\
\text { (Roxb.) } \\
\text { Kuntze }\end{array}$ & Foaceae & Amriso & Herb & Roots & Boils, worms & Paste,extract \\
\hline 57 & $\begin{array}{l}\text { Ramex } \\
\text { nepolensis } \\
\text { S preng. }\end{array}$ & Polygonaceae & Hallale & Herb & $\begin{array}{l}\text { Rhizome/lea } \\
\text { ves }\end{array}$ & $\begin{array}{l}\text { Sptain, arts, } \\
\text { U1cer }\end{array}$ & $\begin{array}{l}\text { Paste, infusion, } \\
\text { vegetable }\end{array}$ \\
\hline 58 & $\begin{array}{l}\text { Cheilanthes } \\
\text { dolhousiae } \\
\text { Hook. }\end{array}$ & Pteridaceae & Ranti sirtka & Herb & whole plant & $\begin{array}{l}\text { U1cer, } \\
\text { s tomachache }\end{array}$ & Plant juice \\
\hline 59 & $\begin{array}{l}\text { Aconitum } \\
\text { ferox } \\
\text { Wall ex }\end{array}$ & Rarminculaceae & Bish & Herb & $\begin{array}{l}\text { I ubercus } \\
\text { root }\end{array}$ & $\begin{array}{l}\text { Nerrousness, } \\
\text { heart problems }\end{array}$ & Powder, juios \\
\hline 60 & $\begin{array}{l}\text { Botentilla } \\
\text { fulggns } \\
\text { Whall. ex } \\
\text { Hook. }\end{array}$ & Rosaceae & Bajradarti & Herb & Roots & $\begin{array}{l}\text { Throat, tooth } \\
\text { infection, peptic } \\
\text { ulcer, cough and } \\
\text { cold }\end{array}$ & Raw, flyste, juice \\
\hline
\end{tabular}


Raghu Ram Parajuli/Study on Local Uses of Medicinal

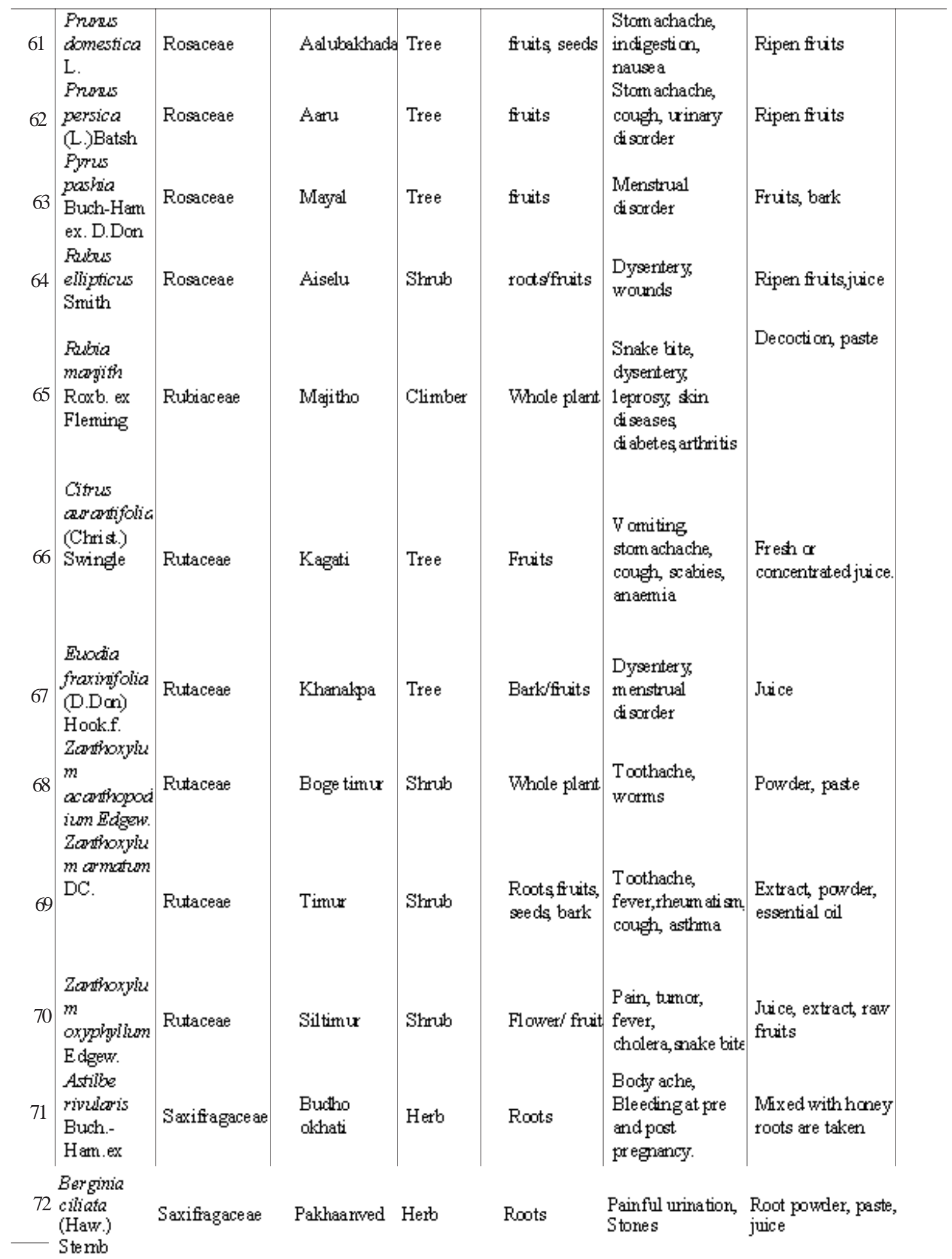


Nepal Journal of Science and Technology Vol. 14, No. 1 (2013) 57-66

\begin{tabular}{|c|c|c|c|c|c|c|c|}
\hline 73 & $\begin{array}{l}\text { Datráa } \\
\text { metel L. }\end{array}$ & Solanaceae & Dhaturo & Herb & Leaf' seed & $\begin{array}{l}\text { Skin d sease, } \\
\text { ulcer, leprosy, } \\
\text { danduff, fever }\end{array}$ & $\begin{array}{l}\text { Leaf juice, paste, } \\
\text { powder }\end{array}$ \\
\hline 74 & $\begin{array}{l}\text { Thicotiona } \\
\text { tabacom L. }\end{array}$ & Solanaceae & Kancho pat & Herb & leaf & Todthache, wounc & Juice paste \\
\hline 75 & $\begin{array}{l}\text { Tanus } \\
\text { wallichiona } \\
\text { Zucc. }\end{array}$ & Taxaceae & Lath salla & Tree & Batk/leaves & $\begin{array}{l}\text { branchitis } \\
\text { hiccough, } \\
\text { indigestion, } \\
\text { cancer }\end{array}$ & Extract \\
\hline 76 & $\begin{array}{l}\text { Centella } \\
\text { asiatica } \\
\text { (L.) Urb. }\end{array}$ & Umbelliferae & Ghortaapre & Herb & Whole plant & $\begin{array}{l}\text { Mental tensicn, } \\
\text { urinary problem, } \\
\text { stam achache, } \\
\text { asthma, fever }\end{array}$ & Leaf juce, paste \\
\hline 77 & $\begin{array}{l}\text { Coriandium } \\
\text { sativon L. }\end{array}$ & Umbelliferae & Dhariya & Herb & Whole fiant & $\begin{array}{l}\text { Cough, } \\
\text { branchitis } \\
\text { theumatisn, } \\
\text { urinary problem }\end{array}$ & $\begin{array}{l}\text { Spice, paste, seed } \\
\text { powder }\end{array}$ \\
\hline 78 & $\begin{array}{l}\text { Heraclem } \\
\text { nopalense } \\
\text { D.Dan }\end{array}$ & Umbelliferae & Chinging & Herb & Rodts'seeds & Cough, diarthoea & $\begin{array}{l}\text { Rod juice, roasted } \\
\text { seeds }\end{array}$ \\
\hline 79 & $\begin{array}{l}\text { Urtica } \\
\text { dicica L. }\end{array}$ & Urticaceae & Sisnoo & Herb & Whole fiant & $\begin{array}{l}\text { Nephritis, } \\
\text { haem aturia, } \\
\text { jaundice, } \\
\text { todhache. }\end{array}$ & Juice, decoction \\
\hline 80 & $\begin{array}{l}\text { Valeriana } \\
\text { jatamansi } \\
\text { Jones }\end{array}$ & Valerianaceae & Sugandhawa & Herb & Whole fiant & $\begin{array}{l}\text { Hysteria, epil eps, } \\
\text { cholera, cough ast } \\
\text { hma, we akness } \\
\text { hairfall }\end{array}$ & $\begin{array}{l}\text { Rod powder, juice, } \\
\text { oils }\end{array}$ \\
\hline 81 & $\begin{array}{l}\text { Amomion } \\
\text { cibrilatom } \\
\text { Raxb. }\end{array}$ & Zingiberaceae & Alaichi & Herb & Seeds & $\begin{array}{l}\text { Indigestion, } \\
\text { vomiting }\end{array}$ & $\begin{array}{l}\text { Whole seed, seed } \\
\text { oil }\end{array}$ \\
\hline 82 & $\begin{array}{l}\text { Corcuma } \\
\text { coesia } \\
\text { Rarb. }\end{array}$ & Zingiberaceae & Kalohaledo & Herb & Rhizames & $\begin{array}{l}\text { Leucoderma, } \\
\text { piles, bronchitis } \\
\text { asthma, sprains }\end{array}$ & Paste, powder \\
\hline 83 & $\begin{array}{l}\text { Karmpferia } \\
\text { rotnda L. }\end{array}$ & Zingiberaceae & Vuinchampa & Herb & Whole $\mathrm{fl}$ ant & $\begin{array}{l}\text { Gastric protems, } \\
\text { tumors, swelling } \\
\text { wound, ulcer. }\end{array}$ & Paste, juice \\
\hline 84 & $\begin{array}{l}\text { Tingiber } \\
\text { officinale } \\
\text { Rosc. }\end{array}$ & Zingiberaceae & Aduwa & Herb & Rhizome & $\begin{array}{l}\text { Limb pain, Joint } \\
\text { pair, } \\
\text { headache,cough, } \\
\text { cold }\end{array}$ & Faste,juice,powder \\
\hline
\end{tabular}


Raghu Ram Parajuli/Study on Local Uses of Medicinal ....

\section{Results and Discussion}

From the study 84 species were recorded belonging to 76 genera and 43 families. Four species of Pteridophytes(Equisetum diffusum, Lycopodium clavatum, Nephrolepsis auriculata and Cheilanthes dalhousiae), one species of Gymnosperms(Taxus wallichiana) and 79 species of Angiosperms were recorded . Asteraceae, Rutaceae and Rosaceae were found as ethnobotanically dominant families each consisting five different species. Families namely Liliaceae, Labiatae, Leguminosae and Zingiberaceae were found as ethnobotanically second dominant families each including four species. From the study 23 families were found with single species. The plants were used to treat many diseases namely diarrhoea, dysentery, urinary troubles, rheumatism, nervousness, heart problem, cough, asthma, malarial fever, constipation, jaundice, burns, indigestion, vomiting, low milk secretion, anemia, bodyache, bleeding(pre and post pregnancy), swelling, leprosy, menstrual disorders, headache, conjunctivitis, stones, irrigation, cholera, gonorrhea, stomachache, scabies, bronchitis, sprains, cuts, ulcer, dandruff, lice problems, sinusitis, syphilis, diabetes, toothache, arthritis, veneral diseases, cold, cancer, etc. Different parts (fleshy stems, shoots, seeds, rhizomes, flowers, barks, leaves, fruits, roots, oils, whole plants, etc.) were used in different forms (vegetable, powder, paste, juice, oil, essential oil, smoke, spice, extract, infusion, mixed etc.) to treat the various diseases. Majority of the studied plants were herbs and their whole plant bodies were used as medicines. Cough, fever, diarrhoea, rheumatism, menstrual disorders, asthma and gastric disorders were more common diseses. Acorus calamus, Asparagus racemosus, Astilbe rivularis, Berginia ciliata, Centella asiatica, Cuscuta reflexa, Euodia fraxifolia, Heracleum nepalense, Ocimum sanctum, Oxalis corniculata, Potentilla fulgens, Rubia manjith, Taxus wallichiana, Valeriana jatamansi, Swertia chirayita, Zingiber officinale like plants were the most frequently used resources. Although there was wide use of plant resources in local communities, the traditional knowledge about medicinal plants seems decreasing generation to generation. The retardation of traditional knowledge on medicinal plants may be due to lack of successor of faith healers, wider use of modern medicine and inadequacy of plants availability(Manandhar \& Chaudhary 1992). It is important to share and document the knowledge on the uses of medicinal plants from older to younger generations. The use of plants as medicine is mainly due to traditional belief and effectiveness of remedies. Elderly people and women in them know more about the medicinal uses of plants. The knowledge can be valuable asset for future generation and economic development of the community. Most of the local people, however are familiar with the value of medicinal plants. They have started cultivation of medicinal plants like Swertia chirayita, Lilium nepalense, Berginia ciliata, Taxus wallichiana, Asparagus racemosus and Valeriana jatamansi. Swertia chirayita, Lilium nepalense and Valeriana jatamansi are in commercial cultivation. Some people are based on the herbal farming for their livelihood. The major market for the medicinal products is India. People are trading the plant resources without caring for their sustainability. So, awareness in the ecological importance of the plants is necessary in the studied area to conserve the rare and important plant genetic resources. Processing and value add mechanism is essential to enhance the economy of local people. Biochemical analysis of the documented plant parts can be another study part. This paper can be useful in the documentation of biodiversity from the study area.

\section{Acknowledgements}

The author is grateful to the Director General of Department of Plant Resources Dr. A.N. Das for his encouragement on research activities. He would like to thank the local people of Nayabazar, Pyang and Jamuna VDCs of Ilam District for their kind cooperation during the study period. He would also like to thank the office members of the District Plant Resources Office, Ilam for their help.

\section{References}

Acharya, S.K. 2009. Ethnobotanical use of some plants in community forests of Kailali district, Far Western Nepal. Bull. Dept. Pl.Res.No.31,pp.114-116.

Anonymous. 2001. Flowering plants of Nepal (Phanerogams). Department of Plant Resources, HMG, Nepal.

Anonymous. 2007. Medicinal plants of Nepal (Revised). Bulletin of Department of Plant Resources no. 28. Department of Plant Resources, Thapathali, Kathmandu, Nepal.

Baral, S.R. and P.P. Kurmi. 2006. A Compendium of medicinal plants of Nepal. Mrs Rachana Sharma, 281 Maiju Bahal, Chabahil, Kathmandu, Nepal. 
Bhatta, G.D. and R.B. Chhetri. 2009. Ethno-medical uses of plants among the Pahari Ethnic community in Badikhel VDC, Lalitpur, Nepal. Bull. Dept. Pl. Res.No 31.pp.108-113.

Bhattarai, S., R.P. Chaudhary and R.S.L. Taylor. 2006. Ethnomedicinal plants used by the people of Manang district, Central Nepal. Journal of Ethnobiology and Ethnomedicine 2(41)._doi:10.1186/1746-4269-2-41.

Gillam, S. 1989. The traditional healers as village health worker. Journal of the Institute of Medicine 11:67-76.

Kunwar, R.M. and R.W. Bussmann 2008. Ethnobotany in the Nepal Himalaya. Jounal of Ethnobiology and Ethnomedicine $4: 24$

Manandhar, L.N. and R.P.Chaudhary 1992. Medicinal plants and their traditional use by tribal people of Saptari district, Nepal. In: Proceedings of First National Botanical Conference Aug.11-12. Kathmandu, Nepal.

Manandhar, N.P. 1980. Medicinal plants of Nepal Himalaya. Ratna Pustak Bhandar, Kathmandu, Nepal.

Manandhar, N.P. 2002. Plants and people of Nepal. Timber Press, Oregon, USA.

Pandey, G. 1995. Medicinal plants of Himalaya, Vol I-II, Sri Satguru Publications, Delhi, India.

Parajuli, R.R. 2003. Study on the inhibitory activity of some plant essential oils against Alternaria brassicicola. Thesis .Central Department of Botany, TU.,Kirtipur, Kathmandu.
Parajuli, R.R. 2011. Study on ethnobotanical plants of Maipokhari wetland area in Ilam, Eastern Nepal. Bull. Dept. Pl.Res.No.33,pp.33-42.

Parajuli, R.R. 2012. Ethnomedicinal use of plants in Rai community of Maimajuwa and Puwamajuwa VDCs of Ilam District, Eastern Nepal. Bull. Dept. Pl.Res.No.34,pp.65-73.

Parajuli, R.R. and U. Thapa. 2066 BS. Major medicinal plants of Ilam district . District plant Resources Office, Ilam.

Patel, N.K. 2010. Ethno-medicinal plants used for amenorrhoea and abnormal menstruation diseases in Danta Taluka (Gujarat). Ethnobotanical Leaflets 14:1- 4 .

Polunin, O. and A. Stainton. 1984. Flowers of Himalaya. Oxford University Press, India.

Rai, S.K. 2007. Aromatic plants of Karnali zone, Midwestern Nepal. Bull. Dept. Pl. Res. No. 29. Department of Plant Resources, Thapathali, Kathmandu, Nepal.

Rajbhandari, K.R. 2001. Ethnobotany of Nepal. Ethnobotanical Society of Nepal. Kathmandu, Nepal.

Shrestha, U. and S.Shrestha. 2061 (B.S.) Major nontimber forest products of Nepal. Bhundipuran Publication, Kathmandu.

Srivastava, D.L.2009. Resources of Nepalese medicinal and aromatic plants: status and development. Bull.Dept.Pl.Res.No.31.pp127-131. 